\title{
The Opinions of Field Experts on Online Test Applications and Test Security During the COVID-19 Pandemic
}

\author{
Hakan Kilinc (iD),*, Muhammet Recep Okur (iD) 1, Ilker Usta (iD)
}

${ }^{1}$ Anadolu University, Open Education Faculty, Department of Distance Education

\author{
ARTICLE HISTORY \\ Received: Feb. 05, 2021 \\ Revised: Oct. 20, 2021 \\ Accepted: Nov. 16, 2021 \\ Keywords: \\ Covid-19, \\ Online test applications, \\ Online test security, \\ Online learning \\ environments, \\ Focus group interview, \\ Case study.
}

\begin{abstract}
Within the scope of this study, it was aimed to determine the factors that should be considered regarding the usability and security of online test applications used as an assessment and evaluation tool during the COVID-19 pandemic. In this context, the case study method was used to obtain the opinions of field experts. Furthermore, in this study, using the focus group interview technique as a data collection technique, the criterion sampling method, one of the purposeful sampling methods, was used to determine participants. At this point, it was taken into consideration that the participants were experts in the field of open and distance learning. In this regard, a total of 15 field experts who have experienced online test during the emergency distance education period at Anadolu University, Turkey contributed to the focus group interviews consisting of three groups. The results obtained at the end of the study offer solutions for the usability of online test applications, the use of which has increased with the pandemic process and ensuring the security of these applications.
\end{abstract}

\section{INTRODUCTION}

With the Covid-19 pandemic spreading so rapidly and affecting the whole world, the flow and rhythm of life have changed worldwide (Zhao, 2020), and a flexible working model has begun to be implemented in working environments to reduce the effect of the pandemic and slow down its spread due to its feature of being highly contagious. The working-from-home model has become one of the most common methods applied in this context. Another field, the operating principle of which has changed, has been the field of education and training (Doghonadze et al., 2020). In this regard, education and training institutions were closed, and face-to-face education was suspended to prevent the increase in COVID-19 cases. In this context, the education of millions of students from all education levels in many countries around the world was interrupted (UNESCO, 2020a). In such a situation, education, one of the basic human rights, was interrupted (UN, 1984). To compensate for this situation, many educational institutions reacted quickly, and emergency remote education applications were put into practice worldwide. At this point, the courses taught in online environments came to the forefront. In this context, although there were many successful and unsuccessful applications in the emergency remote education process, one of the biggest discussions and deficiencies was

\footnotetext{
*CONTACT: Hakan Kilinc $\bigotimes$ hakankilinc@anadolu.edu.tr
} Faculty, Department of Distance Education 
experienced in the assessment and evaluation processes (Bozkurt, 2020). One of these applications is online tests.

The assessment and evaluation process through online tests which are used for the determination of the learning levels of learners and make predictions for the future is carried out by using the information and communication technologies (Gülbahar, 2013; Şimşek, Balaban \& Ergin, 2016; Yağc1 et al., 2015). Online tests usually carried out in online learning environments through learning management systems such as Blackboard, Canvas, and Moodle and question types such as multiple-choice, true-false, short-long answer, gap-filling, and matching have positive effects for learners, instructor, and institutions. These positive effects can be listed as cost and time savings (Şimşek et al., 2016), storage of answers, providing appropriate and quick feedback, ensuring flexibility, high security by reducing human errors (Angus \& Watson, 2009; Jordan \& Mitchell, 2009), less effect of instructor (Anderson et al., 2005), and obtaining quick results (Kuhtman, 2004). Moreover, the fact that online tests are technology-based allows the use of multimedia elements instead of face-to-face exams (Liu, Papathanasiou \& Yung-Wei, 2001). Additionally, online tests also have limitations such as requiring computer and internet access, the possibility of students cheating or the difficult control of whether the student himself/herself takes the exam, and difficult communication (Anderson et al., 2005; Özen, 2016; Sindre \& Vegendla, 2015, Solak et al., 2020). In the studies conducted on online tests within the scope of their positive aspects and limitations, it has been revealed that online tests increase the academic achievement of students (Schmidt et al., 2019), contribute more to academic achievement than the traditional method (Yağc1 et al., 2011) and that students feel more comfortable, fast, efficient, and safe compared to classical exams (Saban et al., 2010). Studies conducted on online tests that are frequently used in online learning environments focus on subjects such as learners' opinions on online tests (Koçak et al., 2006, Saban et al., 2010), the effect of online tests on academic achievement (Yağc1 et al., 2011), the comparison of online tests with traditional exams (Saban et al., 2010; Yağc1 et al., 2011), the effect of online tests on learning and motivation (Marriot, 2009), and the relationship between exam preferences (traditional-online) and performance (Hewson, 2012). However, in this study, online test applications applied in emergency distance education processes that have been implemented with the Covid-19 pandemic process, rather than this wide area on online tests until now, are mentioned. The unpreparedness of many institutions in the emergency distance education process (Bozkurt, 2020; Senel \& Senel, 2021) has caused some disruptions in the implementation of online test applications, as in other distance education applications (Bozkurt, 2020; Can, 2020; d'Orville, 2020) From this point, it can be stated that there is a need for studies on the usability, development, and reliability of online test applications in the emergency of distance education process.

\subsection{Importance of the Study}

Some education and training institutions have suspended the assessment and evaluation practices carried out in face-to-face environments during the COVID-19 pandemic and have started using online test applications (d'Orville, 2020). In a study conducted by UNESCO (2020b), which explains this situation, it is stated that 58 out of 84 countries postponed or rescheduled exams, 23 countries introduced alternative methods such as online or home-based testing, while exams were continued in 22 countries and completely canceled in 11 countries. Therefore, the examination system has been changed in many countries during the pandemic period (Bozkurt, 2020; d'Orville, 2020). In addition to this situation, UNESCO (2020c) emphasized that educational institutions should prepare in the field of assessment and evaluation due to the COVID-19 pandemic. The unpreparedness of educational institutions for the COVID-19 pandemic have required online exam online tests to be carried out without sufficient validity and security reliability studies instead of traditional exams and tests 
(d'Orville, 2020). However, with the emergency distance education applications implemented during the Covid-19 period, the unattended online tests in many institutions have threatened the security of the exam (Bozkurt, 2020; Can, 2020; Senel \& Senel, 2021). The point that should be emphasized here is the usability of online test applications and the security of these exams (Can, 2020; Solak et al., 2020). In this context during the emergency distance education period, what points should be considered while developing online test applications and how a reliable assessment and evaluation process should be carried out emerge as an important situation that needs to be resolved. Moreover, in this period, increasing the security of online test applications is important to eliminate the negativities (possibility of cheating, etc.) caused by these exams. Based on this, it is thought that this study is important in guiding education and training institutions on online test applications, which are becoming increasingly important with the COVID-19 pandemic process, and that these applications can be carried out in line with their purpose. To reach these targeted outputs within the scope of the study, the opinions of field experts who have experienced online tests during the emergency distance education period are needed.

\subsection{Aim of the Study}

This study aims to determine the situations that should be considered regarding the usability and test security on online test applications in the COVID-19 pandemic process according to the opinions of field experts. In this context, answers to the following research questions are sought to achieve the purpose of the study:

1- What should be considered during the development of online test applications during the COVID-19 pandemic?

2- What should be taken into account to ensure the security of online test applications during the COVID-19 pandemic?

At this point, the reason for seeking the opinions of field experts can be listed as follows:

With the Covid-19 pandemic, which emerged unexpectedly, many institutions have had to implement online testing management. For the tests to be applied at this point to be useful and reliable, it is thought that the opinions of field experts who have experienced both the distance education process and the online test application during the pandemic period are guiding. Experts who have had this experience can provide fast and reliable online tests that need to be implemented urgently. To obtain the suggestions of field experts on this subject, their opinions are needed. Therefore, it is thought that one of the most effective ways to reach fast and reliable solutions during the Covid-19 pandemic, in which we have entered the emergency distance education process, is to consult the opinions of field experts who have experienced this process.

The research questions determined within the scope of the study are not related to the general online tests. Instead, these research questions were needed to determine how a reliable online test system should be implemented to minimize the problems that may arise after the use of unattended online test applications in the emergency distance education process.

\section{METHOD}

This study was designed with a case study, one of the qualitative research approaches. The case study that forms the pattern of this research is based on in-depth analysis of any event, individual or process based on data (Creswell, 2007). According to Yin (2003), case study is a method that investigates the phenomenon in the existing natural environment and is used in cases where the existing situation and the environment in which it is located are not separated by precise lines. Case studies are defined as a research method that works in a real case within its real-life framework, where the boundaries between the case and the environment in which it is located are not evident and there is more than one source of evidence or data (Yin, 1984). 
From this point of view, in this research, a document analysis including the applications related to the study was carried out. Then the opinions of field experts were consulted on the development and reliability of online tests applied by many educational institutions during the Covid-19 pandemic period when the emergency distance education process was started.

\subsection{Study Group}

The criterion sampling method, one of the purposeful sampling methods, was preferred in this study. The basic understanding of the criterion sampling method is to study all situations that meet a predetermined set of criteria. A set of previously prepared criteria can be used here as developed by the researchers (Yıldırım \& Şimşek, 2011). As a criterion, it was considered that the participants were experts in the field of open and distance learning. A total of 15 participants who had experienced online tests during the distance education period, contributed to the study performed within this scope. The demographic information of the participants is presented in Table 1.

Table 1. Demographic Information of Participants.

\begin{tabular}{lcl}
\hline Participant (Pseudonym) & Gender & Title \\
\hline Masal & Female & Prof. Dr. \\
\hline Cengiz & Male & Prof. Dr. \\
\hline Hasan & Male & Prof. Dr. \\
\hline Ahmet & Male & Prof. Dr. \\
\hline Gülay & Female & Prof. Dr. \\
\hline Okan & Male & Prof. Dr. \\
\hline Mustafa & Male & Prof. Dr. \\
\hline Ali & Male & Prof. Dr. \\
\hline Resul & Male & Assoc. Dr. \\
\hline Anıl & Male & Assoc. Dr. \\
\hline Tuna & Male & Assoc. Dr. \\
\hline Hakan & Male & Assoc. Dr. \\
\hline Cihan & Male & Assoc. Dr. \\
\hline Frat & Male & Assoc. Dr. \\
\hline Esra & Female & Assoc. Dr. \\
\hline
\end{tabular}

\subsection{Data Collection Tool}

The interview is the basic data collection technique in the case study design (Ersoy, 2013). In revealing experiences and meanings related to the phenomena, the interview technique provides researchers with interaction, flexibility, and opportunities to examine them through probes (Y1ldırım \& Şimşek, 2008). In this context, the focus group interview was used to obtain data within the scope of this study. The focus group interview (Bloor et al., 2001), which is commonly used in academic studies, is a technique of using the effect of group dynamics, obtaining in-depth information, and generating ideas in the interview process between a small group and the moderator (Bowling, 2002; Yıldırım \& Şimşek, 2008). Krueger (1994) defines the focus group interview as a carefully planned discussion in an environment where individuals can freely express their thoughts. The purpose of focus group interviews is to obtain in-depth, detailed, and multidimensional qualitative information about the participants' perspectives, lives, interests, experiences, tendencies, thoughts, perceptions, feelings, attitudes, and habits on a specified subject (Bowling, 2002). The important thing in focus group interviews is creating 
an environment where participants can freely express their opinions. In this sense, the most significant advantage of focus group interviews is that new and different ideas emerge from within-group interaction and group dynamics (Kitzinger, 1995). Focus group interviews, led by a moderator, using the techniques of asking questions, discussing, and summarizing to reveal the thoughts and experiences of participants, consist of a maximum of 10 or 12 participants (Karabekir et al., 2015). Within the scope of this study, a total of three focus group interviews, consisting of five participants each, were held. A moderator guided each group in the focus group interviews. During the interview, it was ensured that the participants sat in a U shape, and a pen and paper were placed on the tables. In the introduction part, the purpose of the study was explained, and the interviews were started after the participants introduced themselves briefly. Care was taken to ensure that the group participants consisted of experts in the open and distance learning field. In the groups where semi-structured interviews lasted approximately 90 minutes were conducted, the moderators recorded the data.

Semi-structured interview questions consisting of two questions were used to obtain the participants' opinions about the online test applications carried out at Anadolu University and exam security during the COVID-19 pandemic period. Before the interviews, the content validity of the semi-structured interview form was ensured by obtaining the opinions of three experts working on qualitative research methods, and it was finalized.

\subsection{Data Analysis}

The content analysis method was used in the data analysis. The main purpose of content analysis is to reach the concepts and relationships that can explain the collected data. To this end, the data collected must first be conceptualized, then organized logically according to the resulting concepts, and the themes explaining the data must be determined accordingly (Yildirim \& Şimşek, 2011). In this context, at the end of the focus group interviews, the reports prepared by the moderators working in each group were transferred to the computer environment, and the content analysis stage was initiated. The content analysis performed within the scope of the study was conducted using NVIVO 12 qualitative data analysis program. Codes were determined as a result of the content analysis of the raw data obtained from the interviews. At this point, the collected data were analyzed separately by two independent researchers, and the numbers of consensus and disagreement were determined by comparing the coding made by independent researchers. Reliability was calculated using these numbers using the formula $($ Reliability $=$ Agreement/(Agreement + Disagreement) $)$ suggested by Miles and Huberman (1994). The reliability among researchers was found to be $90 \%$. The codes obtained are presented in the findings section of the study.

\section{FINDINGS}

The findings obtained in light of the questions asked to the participants within the scope of this study are presented below.

\subsection{The Findings Obtained Regarding the Development of Online Test Applications During the COVID-19 Pandemic Period}

The first question asked to the participants within the scope of the study was which points should be taken into consideration in the development of online test applications. The findings obtained in this context are presented in Figure 1. 
Figure 1. Recommendations for the development process of online test applications.

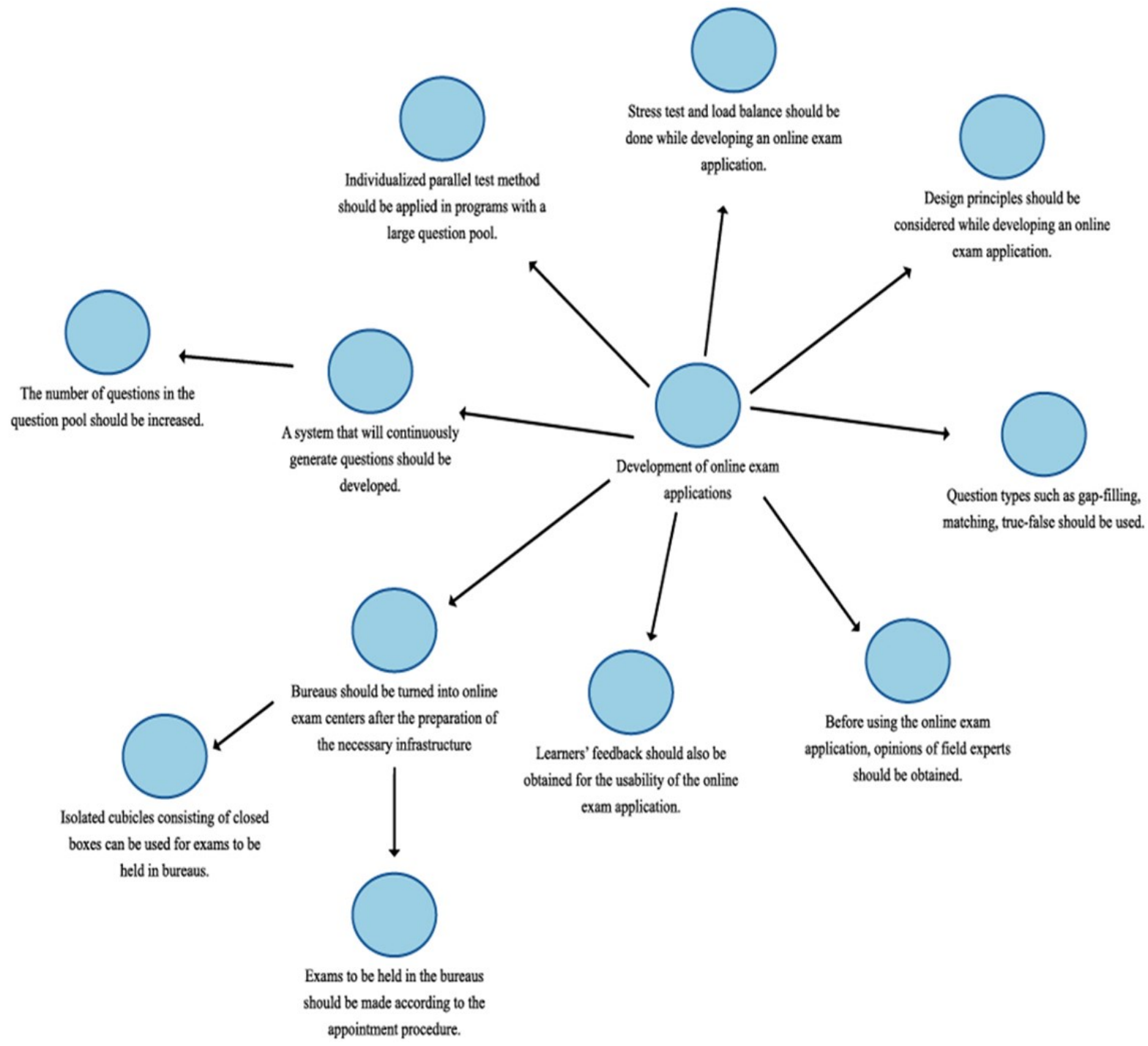

A total of 9 sub-themes were reached under the main theme of developing online test applications. Among these themes, the most repeatedly sub-theme was "Bureaus should be turned into online test centers after the preparation of the necessary infrastructure." The emergence of this sub-theme originates from the fact that the participants work at Anadolu University. The Open Education Faculty was established within Anadolu University in 1982. From 1982 to the present day, open education bureaus have been working throughout the country to provide services to learners within the scope of the Open Education Faculty with more than three million students, both active and passive. As of 2020, a total of 102 open education bureaus have been serving actively across Turkey. In this context, it can be stated that this theme, obtained for the use of bureaus as examination centers within the scope of the study, originates from the experience of the participants of Anadolu University Open Education Faculty. The prominent views obtained under this theme are as follows:

"Online tests supervised in bureaus can be conducted by appointment. Thus, bureaus can be turned into online test centers. At this point, necessary infrastructure should be prepared in bureaus. " Cengiz

"Isolated cubicles consisting of closed boxes can be used in the online test system to be realized in bureaus. Students can take an exam by making an appointment in a supervised way at these points." Hasan 
The subjects emphasized under the sub-theme "Bureaus should be turned into online test centers after the preparation of the necessary infrastructure" were the subjects of using isolated cubicles consisting of closed boxes in online tests to be carried out through bureaus and conducting exams to be held in bureaus according to the appointment method. In this context, it was also stated that the examination process should be spread over a wide period. Another sub-theme emphasized under the main theme of the development of online test applications was the theme "A system must be developed to generate questions continuously." Some of the opinions obtained in this context are as follows:

"The number of questions in the question pool should be increased so that online tests can be applied efficiently." Ahmet

"The more questions there are in the question pool, the more applicable online tests will be." Esra

"A system that will continuously generate questions by spreading the question preparation process over time should be developed." Cihan

Another sub-theme obtained under this main theme was the types of questions to be asked in exams. In this context, the prominent opinions among those obtained under the sub-theme "Question types such as gap-filling, matching, true-false should be used" are as follows:

"The opportunities of technology can be used in online tests. For example, question types such as gap-filling, matching, true/false questions can be diversified." Firat

"In addition to multiple-choice questions, other question types should also be included in technology-based online tests. " Ali

In addition to these sub-themes obtained under the main theme of "Developing online test applications," the sub-themes of "Stress test and load balance should be performed while developing an online test application" and "The opinion of field experts should be obtained before using the online test application" were also included. In this context, field experts emphasized the necessity of performing all necessary tests before using online test applications and consulting experts in the field in this process. Moreover, under the sub-theme "For the usability of the online test application, students' opinions should also be obtained," it was stated that learners' opinions should also be consulted to see the equivalent of the online test application used in learners. Finally, under the sub-theme of "Design principles should be taken into consideration while developing an online test application," it was mentioned that design principles should be considered for the developed exam system to be user-friendly.

\subsection{The findings obtained to ensure the security of online test applications carried out during the COVID-19 pandemic period}

The second question asked to the participants within the scope of the study was about the factors that should be considered to ensure the security of online test applications. The findings obtained in this context are presented in Figure 2. 15 sub-themes were reached under the main theme of the security of online test applications. The themes were about how to hold the exams to be applied in online environments securely. The sub-themes obtained in this context focused on preventing the students who would take an exam from receiving help from anyone other than themselves. Accordingly, the most remarkable themes were the following themes: "Behavioral biometric techniques such as writing style on the keyboard, speaking style, and signing style should be used," "Information security processes such as identification, authentication and authorization should be used," "Physiological biometric techniques such as fingerprint recognition, eye-iris recognition should be used," "The full-screen lock application should be used," "Browser lock should be functionalized," and "360-degree cameras should be used." The opinions obtained within the scope of these themes were expressed to prevent 
learners who would take an exam in online environments from receiving help from anyone other than themselves. The most repeated among these opinions are as follows:

"To prevent learners who will take an exam in online environments from receiving help from others, biometric techniques such as writing style on the keyboard, speaking style, and signing style should be used." Resul

"By using full-screen lock and browser lock applications, we can eliminate the possibility of learners accessing screens other than the exam screen." Cengiz

"If a 360-degree camera system is installed, the exam environment can be completely controlled." Anil

"Physiological biometric techniques such as fingerprint recognition and eye-iris recognition can be used to be sure of the student's identity in online tests to be carried out through bureaus." Tuna

Figure 2. Suggestions for the security of online test applications.

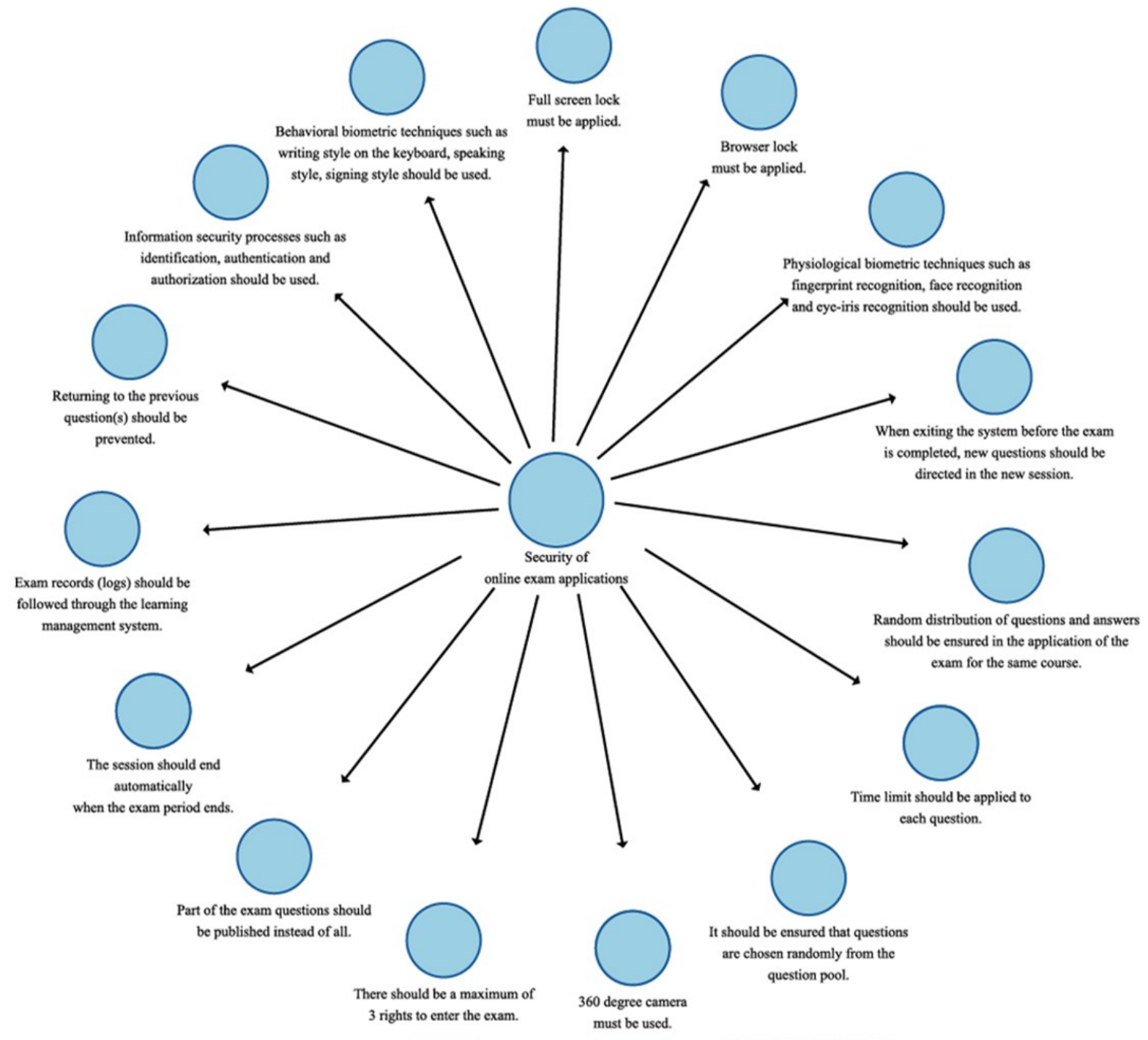

Furthermore, for learners not to receive help via other pages over the Internet or through any application during the exam, opinions were obtained under the following themes "A certain time limit should be set for each question," "Maximum 3 rights should be granted to enter the exam," "New questions should be directed in the new session when the exam is exited before its completion," "The session should be automatically terminated when the exam time is over," 
"Exam records (logs) should be followed through the learning management system," "Returning to the previous question-questions should be prevented." At this point, it can be stated that the experiences gained at Anadolu University played a role in the themes obtained. In the online test application applied by Anadolu University Open Education Faculty during the COVID-19 period, when a student enters the online test system, he/she can see all the courses in the relevant semester. He/she can choose for which course he/she wants to take an exam. Before the online test starts, the necessary exam rules are presented to the student.

When the exam is started, the internet browser opens in full screen, and the time starts to run. The system ends the exam when the student tries to exit the browser and open another web browser. The student continues the exam with the remaining question and the remaining time by logging into the system again. Only in this way, there is a right to a total of three re-entries. The right to re-enter the system has been defined in a limited number for students not to suffer due to browser problems, internet, electric cut-outs, etc. When the student starts the exam, each question comes up once. If the student leaves the question blank, he/she cannot return to the relevant question again. He/she saves the relevant answer of each question by marking it and moves on to the next question. No return can be made to the question left blank and answered. Therefore, it can be stated that the experiences gained by the participants during the online test application play a role in these themes. The prominent opinions among the opinions obtained are as follows:

"If a certain time limit is set for each question, learners will not have the opportunity to obtain information from other pages or other applications. At this point, field experts should determine how much time will be given to which question." Okan

"The application that allows cheating in the exam currently applied is that students can exit the exam and take the exam again from where they have left it. When the student exits the exam, new sessions and new questions should be directed, and a maximum of 3 rights should be granted." Masal

"By examining the exam logs kept by learning management systems, information about how long learners are browsing outside the exam screen can be obtained." Gülay

"Not allowing to return to the previous question will minimize the chance for learners to find answers to questions from elsewhere." Mustafa

Moreover, under the theme "The random distribution of questions and answers should be ensured in the application of the exam for the same course," it was emphasized that the possibility of learners taking the exam at the same time and in the same course to answer questions together should be eliminated. Furthermore, under the theme "Not all of the exam questions should be published, but a certain part," it was emphasized that the question pools prepared for use in online tests should consist of more and better-quality questions.

\section{DISCUSSION and CONCLUSION}

The first findings obtained within the scope of this study, in which the opinions of field experts were obtained on the development of online test applications that became more needed with the COVID-19 pandemic period and the security of these applications, were on the points that should be taken into consideration during the development of online test applications. In this context, it was concluded that visual design principles should come to the forefront in developing online test applications. It is an important element to use visual design principles to serve the purpose of the online tests to be carried out and to have a user-friendly interface. In a study performed by Albayrak (2014) on this issue, it was concluded that learner achievement was higher in online tests designed by considering visual design principles. In the studies conducted by Ortner and Caspers (2001) and Clough (2008), it was revealed that learners' achievement was affected by the quality of the exam. In another study carried out by Yağc1 et 
al., (2015), it was mentioned that an online test application developed in line with the visual design principles would reduce learners' anxiety about taking exams in online environments. Therefore, it can be said that visual design principles should be put into practice during the development of online test applications.

Another result obtained within the scope of the study was related to the necessity of receiving opinions from both field experts and learners in developing online test applications. In this context, after the online test application is developed, it should be opened to field experts before it is put into use, and it was concluded that opinions on the usability of the application should be obtained from them. In addition to this, after the developed application was put into use, it became necessary to obtain students' opinions about the experiences they gained during their use of the application. In this way, the deficiencies of the developed application will be determined, and studies will be carried out to eliminate the identified deficiencies by taking opinions from both field experts and learners. In the studies conducted by Koçak et al. (2006), Saban et al. (2010), and Yilmaz (2016) on this issue, it was emphasized that the views of students, which should be at the focus of learning and teaching activities, should be attached importance in the process of developing online test applications. A study performed by Sırakaya, Sırakaya and Çakmak (2015) investigated the attitude levels of distance learners toward online tests. At the end of the study, it was concluded that most of the learners had a positive opinion about online tests. According to Kınalığlu and Güven (2011), it is important to obtain opinions and suggestions from field experts in the process of developing online test applications for the application to be successful. Another important result reached at this point is that the stress test and load balance of the developed online test application should be performed. In line with this result obtained, Wang (2017) emphasized that stress testing and load balance should be considered to check the usability of online test applications.

Another result obtained within the scope of the opinions of field experts was on the question types to be used in online test applications. Accordingly, while developing online test applications, attention should be paid to the use of question types such as gap-filling, short-long answer, matching, true-false, in addition to multiple-choice questions. In line with this result, Borich (2013) indicated that question types such as true-false, matching, multiple-choice, completion, open-ended questions should be used in online tests.

Another issue emphasized during the development of online test applications was related to expanding the question pool. In line with this, in a study conducted on the design of online tests, Jiang et al. (2019) stated that more questions produced by field experts using various question types were important for the usability of online test applications, so by providing the diversity of questions, applications such as the individualized parallel testing method could be used. Therefore, it can be stated that the number of questions should be higher for a more efficient online testification process. In this context, under the theme of "a system that will continuously generate questions should be developed" obtained within the scope of the study, field experts emphasized that the number of questions should be high.

Another result obtained about the usability of online test applications is that after the necessary infrastructure is provided, online tests must be conducted in exam centers to be determined in certain regions. In this context, it was concluded that bureaus could be used within Anadolu University, the institution where the study was conducted. Likewise, it can be stated that other institutions can determine specific examination centers in certain regions and carry out online tests. At this point, the issues that should be focused on are providing the necessary infrastructure and conducting exams according to the appointment method. In a study conducted on online tests, Yağc1 et al. (2015) stated that online tests could be held entirely in web-based environments or physical spaces such as exam centers, high schools, and conference halls. Therefore, it can be said that online test applications can be carried out in web 
environments or physical spaces, considering the requests and infrastructure possibilities of institutions.

Another research question for which the opinions of field experts were obtained within the scope of the study was on the security of online tests. Based on the findings obtained in this context, the first result was on the use of biometric and physiological biometric techniques. It was concluded that measures such as writing style on the keyboard, speaking style, and signing style could be used within the scope of biometric techniques. It is stated that techniques such as fingerprint recognition, face recognition, and eye-iris recognition could be used within the scope of physiological biometric techniques. In this context, it can be said that biometric techniques can be used in online tests held in the web environment, and physiological biometric techniques can be used in online tests held through exam centers such as bureaus, high schools, and conference halls. In this way, the security of online test applications can be further increased, and behaviors such as cheating and plagiarism can be prevented. In line with these results obtained within the scope of the study, Kaya (2016) and Patil, Sharma and Patil (2019) mentioned that physiological biometric techniques such as face recognition could be used effectively in online test applications. Likewise, Bozkurt and Uçar (2018) and Senthil Kumar and Rathi (2021) emphasized that biometric and physiological biometric techniques should be used to eliminate limitations such as cheating and plagiarism in online tests.

It was concluded that another measure to ensure the security of online test applications was to employ information security processes such as identification, authentication, and authorization. The use of biometric and physiological biometric techniques and information security processes will eliminate the situation when someone other than the student who will take the exam in online environments will take the exam. Therefore, a more reliable and appropriate examination process will be carried out. Similar to this result, in the study conducted by Parker (2010), it was emphasized that possible threats to confidentiality, integrity, and compliance could be prevented by using information security processes in online tests. Considering that cheating incidents have increased in recent years (Jisc, 2020), it can be stated that it is a necessity to take security measures in this way.

Another dimension that would ensure the security of online tests within the scope of the study was the measures to be taken at the time of the exam. In this context, issues such as using the browser lock, applying the full-screen lock, granting up to 3 rights to enter the exam, directing new questions in the new session when exiting the system before the exam is completed, closing the system after the exam period are over, examining records through the learning management system, the inability to return to the previous question, and setting the time limit for each question were emphasized. Thanks to these measures to be taken, it is aimed to prevent learners from seeking answers to questions through another application or another Web page. Furthermore, giving the maximum of 3 rights to learners who exit the exam for any reason before completing the exam and updating the remaining questions as new questions when they take the exam again is another type of security that can be applied. Similar to these results obtained, Can (2020) and Karthika et al., (2019) stated that measures such as setting a certain time limit for each question, using screen and browser locks, and not displaying previous questions could be used in online test applications.

Another result obtained in ensuring the security of online tests is the use of a 360-degree camera system. In this context, the 360-degree camera application, including an audio system, it aims to fully control the environment in which students take online tests. In this way, learners will be prevented from attempting to cheat. In line with this result, Golden and Kohlbeck (2020) and Hylton et al. (2016) stated that the webcam-based exam system was useful for preventing misuse in online tests. Furthermore, in a study performed by Hoque, Ahmed, Uddin and Faisal 
(2020), 360-degree cameras were used in the online test application process and were considered a successful application in terms of their results.

As a result, the increasing use of online learning environments, especially with the COVID-19 pandemic process, has become a situation that increases the importance of online test applications in evaluating the education and training process. Considering that instructor and learners exhibit positive attitudes toward online test applications (Can, 2020; Fatmasari, 2020, Gül, 2012; Harnkajornsuk et al., 2019; Sirakaya et al., 2015; Y1lmaz, 2016), it emerges as an important point that these applications are usable and reliable (Kundu \& Bej, 2021). However, the fact that institutions were generally unprepared for the emergency distance education applications implemented during the pandemic (Bozkurt, 2020; Senel \& Senel, 2021) made it difficult to realize a healthy measurement-evaluation process. In this context, seeking the opinions of experts who have experience in online test applications during the emergency distance education period will guide the institutions on how these applications should be done and how to obtain reliable results. Therefore, as mentioned in the introduction section of the study, this can be shown as an example of the new perspectives brought to education and training practices with the COVID-19 pandemic process.

\subsection{Recommendations}

The recommendations that can be made based on the results obtained within the scope of the study are listed in the following way:

- Technological infrastructure systems and workforce requirements should be met by institutions to evaluate short and long-answer question types that can be used in online test applications.

- Assessment-evaluation, research and development (R\&D) units should be established for technological infrastructures institutions should provide, and individuals with high technological knowledge should be employed in these units.

- While the question pool is increased during the development of online test applications, field domain experts should check the scope, validity, and reliability of the questions to be prepared. For this process, institutions should establish units within their organization and benefit from the knowledge and experience of field experts through these units.

- Individuals who will supervise the exam environment will be needed during the 360 -degree camera application process. In this regard, it is important to conduct exams according to the appointment procedure and use the workforce efficiently.

- Obtaining learners' biometric and physiological biometric properties to ensure the security of exams in online environments brings about ethical concerns. In this context, it is important to attach importance to data confidentiality and act in line with ethical rules.

- Learning processes should be addressed as a whole, and a process should be evaluated at the point of assessment and evaluation. In this context, in addition to a midterm and final exams to be carried out in online environments, elements such as data to be obtained from learning analytics, assignments, activities in the discussion forum should be evaluated in assessment and evaluation processes.

\section{Declaration of Conflicting Interests and Ethics}

The authors declare no conflict of interest. This research study complies with research and publishing ethics. The scientific and legal responsibility for manuscripts published in IJATE belongs to the author(s). Ethics Committee Approval and its number should be given by stating the institution name which gave the ethical approval. Ethics Committee Number: Anadolu University, 60779. 


\section{Authorship Contribution Statement}

Hakan Kilinc: Investigation, Introduction, Importance of the Study, Purpose of the Study, Method, Data Analysis, Discussion, Conclusion, and Recommendations. Muhammet Recep Okur: Investigation, Method, Data Analysis, Visualization, Software, Findings, Discussion, Conclusion, and Recommendations. Ilker Usta: Investigation, Data collection, Discussion, Conclusion, and Recommendations

\section{ORCID}

Hakan KILINC (D) https://orcid.org/0000-0002-4301-1370

Muhammet Recep OKUR (iD https://orcid.org/ 0000-0003-2639-4987

Ilker USTA (iD https://orcid.org/ 0000-0002-6403-6294

\section{REFERENCES}

Abduh, M. Y. M. (2021). Full-time online assessment during covid-19 lockdown: EFL teachers' perceptions. Asian EFL Journal, 28(1), 1-21.

Albayrak, E. (2014). Elektronik Ortamlardaki Sınavlarda Tasarım Etmenlerinin Öğrencilerin Başarıları ve Elektronik Sınav Kaygılarına Etkisi [The Effects of Design Factors on Students' Success and Test Anxiety in Electronic Tests]. International Online Journal of Educational Sciences, 6(2), 460-474.

Anderson, H. M., Cain, J., \& Bird, E. (2005). Online course evaluations: Review of literature and a pilot study. American Journal of Pharmaceutical Education, 69(1), 34-43.

Angus, S.D., \& Watson J. (2009) Does regular online testing enhance student learning in the numerical sciences? Robust evidence from a large data set. British Journal of Educational Technology, 40, 255-272. https://doi.org/10.1111/j.1467-8535.2008.00916.x

Bloor, M., Frankland, J., Thomas, M., \& Robson, K. (2001). Focus Groups in Social Research. SAGE.

Borich, G. D. (2013). Effective teaching methods (8 ed.). England: Person Education.

Bowling, A. (2002). Research Methods in Health: Investigating Health and Health Services. McGraw-Hill House.

Bozkurt, A. (2020). Koronavirüs (Covid-19) pandemi süreci ve pandemi sonrası dünyada eğitime yönelik değerlendirmeler: Yeni normal ve yeni eğitim paradigması [Coronavirus (Covid-19) pandemic process and educational evaluations in the post-pandemic world: New normal and new education paradigm]. AUAd, 6(3), 112-142.

Bozkurt, A., \& Sharma, R. C. (2020). Emergency remote teaching in a time of global crisis due to CoronaVirus pandemic. Asian Journal of Distance Education, 15(1), i-vi. https://doi.org/10.5281/zenodo.3778083

Bozkurt, A., \& Uçar, H. (2018). E-Öğrenme ve e-sınavlar: Çevrimiçi ölçme değerlendirme süreçlerinde kimlik doğrulama yöntemlerine ilişkin öğrenen görüşlerinin incelenmesi [ELearning and e-exams: Examination of learner views on identity verification methods in online assessment and evaluation processes]. Mersin Üniversitesi Eğitim Fakültesi Dergisi, 14(2), 745-755. https://doi.org/10.17860/mersinefd.357339

Can, E. (2020). Coronavirüs (Covid-19) pandemisi ve pedagojik yansımaları: Türkiye'de açık ve uzaktan eğitim uygulamaları [Coronavirus (Covid-19) pandemic and pedagogical implications: open and distance education applications in Turkey]. AUAd, 6(2), 11-53.

Clough, S. J. (2008). Computerized versus paper and pencil assessment of socially desirable responding: score congruence, completion time, and respondent perefences [Unpublished doctoral dissertation]. The University of Iowa, USA.

Creswell, J. W. (2007). Qualitative inquiry and research method: Choosing among five approaches. Academic Press. Sage. 
d'Orville, H. (2020). COVID-19 causes unprecedented educational disruption: Is there a road towards a new normal? Prospects, 2020(49), 11-15. https://doi.org/10.1007/s11125-020$\underline{09475-0}$

Doghonadze, N., Aliyev, A., Halawachy, H., Knodel, L., \& Adedoyin, A. S. (2020). The Degree of Readiness to Total Distance Learning in the Face of COVID-19-Teachers' View (Case of Azerbaijan, Georgia, Iraq, Nigeria, UK and Ukraine). Journal of Education in Black Sea Region, 5(2), 2-41. https://doi.org/10.31578/jebs.v5i2.197

Ersoy, A. (2013). Türk öğretmen adaylarının kültürlerarası deneyimlerinde karşılaştıkları sorunlar: Erasmus değişim programı örneği [Problems faced by Turkish teacher candidates in their intercultural experiences: Erasmus exchange program example]. Eğitim ve Bilim, 38(168), 154-166.

Fatmasari, R. (2020). Student satisfaction on distance education academic services. In International Conference on Education, Science and Technology (pp. 31-37). Redwhite Press.

Golden, J., \& Kohlbeck, M. (2020). Addressing cheating when using test bank questions in online Classes. Journal of Accounting Education, 52(2020), 1-14. https://doi.org/10.101 6/j.jaccedu.2020.100671

Gülbahar, Y. (2013). E-değerlendirme.[ E-evaluation], K. Çağıltay, Y. Göktaş. (Eds.). Öğretim Teknolojilerinin Temelleri: Teoriler, Araştırmalar, Eğilimler [Foundations of Instructional Technology: Theories, Research, Trends], pp. 651-663. Pegem Akademi Yayıncılık

Harnkajornsuk, S., Chinda, B., Witayasakpan, S., Wongboonnak, S., \& Bunto, P. A. S. (2019). Development of a Web-based Online Examination for Screening Gifted Students. In Proceedings of the 2019 8th International Conference on Educational and Information Technology (pp. 56-60).

Hewson, C. (2012). Can Online Course-Based Assessment Methods Be Fair and Equitable? Relationships between Students' Preferences and Performance Within Online and Offline Assessments. Journal of Computer Assisted Learning, 28(5), 488-498. https://doi.org/10.1111/j.1365-2729.2011.00473.x

Hoque, M. J., Ahmed, M. R., Uddin, M. J., \& Faisal, M. M. A. (2020). Automation of Traditional Exam Invigilation using CCTV and Bio-Metric. International Journal of Advanced Computer Science and Applications, 11(6), 392-399.

Hylton, K., Levy, Y., \& Dringus, L. P. (2016). Utilizing webcam-based proctoring to deter misconduct in online exams. Computers \& Education, 92(2016), 53-63. https://doi.org/10.1016/j.compedu.2015.10.002

Jiang, J., Wu, B., Chang, L., Liu, K., \& Hao, T. (2019). The Design and Application of an WebBased Online Examination System. International Symposium on Emerging Technologies for Education (pp. 246-256). Springer, Cham.

Jisc (2020). The future of assessment: five principles, five targets for 2025. https://repository.jisc.ac.uk/7733/1/the-future-of-assessment-report.pdf

Jordan, S., \& Mitchell T. (2009) e-Assessment for learning? The potential of short-answer freetext questions with tailored feedback. British Journal of Educational Technology, 40(2), 371-385. https://doi.org/10.1111/j.1467-8535.2008.00928.x

Karabekir, M., Tozlu, E., \& Şencan, M. N. M. (2015). Girişimci Adayı Üniversite Öğrencilerinin Girişimcilik Özelliklerinin Odak Grup Görüşmesi ile İncelenmesi [Investigation of Entrepreneurial Characteristics of University Students who are Entrepreneur Candidates with a Focus Group Meeting]. SDÜ Fen Edebiyat Fakültesi, Sosyal Bilimler Dergisi, 1(35), 203-216. 
Karthika, R., Vijayakumar, P., Rawal, B. S., \& Wang, Y. (2019). Secure Online examination System for e-learning. 2019 IEEE Canadian Conference of Electrical and Computer Engineering (CCECE) (pp. 1-4). IEEE.

Kaya, Z. (2016). Biyometrik Güvenlik Sistemleri ve Yüz Tanımaya Dayalı Çevrimiçi Sınav Sistemi [Biometric Security Systems and Online Exam System Based on Face Recognition] [Unpublished doctoral dissertation]. İstanbul Aydın University.

Kınalığlu, İ. H., \& Güven, Ş. (2011). Uzaktan Ĕ̈itim Sisteminde Öğrenci Başarısını Ölçülmesinde Karşılaşılan Güçlükler ve Çözüm Önerileri [Difficulties Encountered in Measuring Student Achievement in Distance Education System and Solution Suggestions]. XIII. Akademik Bilişim Konferans1, Malatya.

Kitzinger, J. (1995). Qualitative research: introducing focus groups. British Medical Journal, 31(7000), 299-302.

Koçak, Ş., Yenilmez, E. D., \& Yenilmez, E. (2006). Çevrimiçi Sınav Sistemlerinin Öğrenmeye Olan Etkileri Üzerine Bir Çalışma: Öğrenci Görüşleri [A Study on the Effects of Online Exam Systems on Learning: Student Views]. Çukurova Üniversitesi Ilahiyat Fakültesi Dergisi, 6(2), 171-189.

Krueger, R.A. (1994). Focus Groups: A Practical Guide For Applied Research. SAGE.

Kuhtman, M. (2004). Review of online student ratings of instruction. College and University Journal, 80(1), 64-67.

Senthil Kumar, A.V., \& Rathi, M. (2021). Keystroke Dynamics: A Behavioral Biometric Model for User Authentication in Online Exams. In M. Khosrow-Pour (Ed.), Research Anthology on Developing Effective Online Learning Courses (pp. 1137-1162). IGI Global.

Kundu, A., \& Bej, T. (2021). Experiencing e-assessment during COVID-19: an analysis of Indian students' perception. Higher Education Evaluation and Development, 15(2), 114 134. https://doi.org/10.1108/HEED-03-2021-0032

Liu, M., Papathanasiou E., \& Yung-Wei H. (2001) Exploring the use of multimedia examination formats in undergraduate teaching: results from the fielding testing. Computers in Human Behavior, 17(3), 225-248. https://doi.org/10.1016/S07475632(01)00008-5

Marriot, P. (2009). Students' Evaluation of The Use of Online Summative Assessment on an Undergraduate Financial Accounting Module. British Journal of Educational Technology, 40(2), 237-254. https://doi.org/10.1111/j.1467-8535.2008.00924.x

Ortner T. M. \& Caspers, J. (2001). Consequences of test anxiety on adaptive versus fixed item testing. European Journal of Psychological Assessment, 27(3),157-163.

Özen, Z. (2016). Kimlik Doğrulaması için Tuş Vuruş Dinamiklerine Dayalı Bir Güvenlik Sisteminin Yapay Sinir A ğlart ile Geliştirilmesi [Development of a Security System Based on Keystroke Dynamics for Authentication with Artificial Neural Networks] [Unpublished doctoral dissertation]. İstanbul University.

Parker, D. (2010). Our excessively simplistic information security model and how to fix it. ISSA Journal, 8(7), 12-21.

Patil, S., Sharma, Y. K., \& Patil, R. (2019). Implications of Deep Learning-Based Methods for Face Recognition in Online examination System. International Journal of Recent Technology and Engineering, 8(3), 14-27.

Saban, A., Özer, H. İ., \& Tümer, A. E. (2010). Çevrimiçi ders materyalleri ve çevrimiçi sınav sistemi ile ilgili öğrenci görüşleri [Student views on online course materials and online exam system]. E-Journal of New World Sciences Academy, 5(4), 2238-2244.

Schmidt, R. A., Lee, T. D., Winstein, C. J., Wulf, G., Zelaznik, H. N. (2019). Motor control and learning: a behavioral emphasis. Human Kinetics. 
Senel, S., \& Senel, H. C. (2021). Remote Assessment in Higher Education during COVID-19 Pandemic. International Journal of Assessment Tools in Education, 8(2), 181-199. https://doi.org/10.21449/ijate.820140

Şimşek, İ., Balaban, M., \& Ergin, H. (2016). Eğitimde Ölçme ve Değerlendirme Çalışmalarında Web Tabanlı Uzman Sınav Sisteminin Kullanımı Üzerine Bir Araştırma [A Research on the Use of Web Based Examination System in Education Measurement and Evaluation Studies]. Hasan Ali Yücel Eğitim Fakültesi Dergisi, 13(26), 165-179.

Sindre, G., \& Vegendla, A. (2015). E-exams versus paper exams: A comparative analysis of cheating-related security threats and countermeasures. NISK Journal, 8(1), 34-45.

Sırakaya, M., Sırakaya, D. A., \& Çakmak, E. K. (2015). Uzaktan Eğitim Öğrencilerinin Çevrimiçi Sinava Yönelik Tutum Düzeylerinin İncelenmesi [Investigation of Distance Education Students' Attitudes towards Online Exam]. Kastamonu Eğitim Dergisi, 23(1), 87-104.

Solak, H.İ., Ütebay, G., \& Yalçın, B. (2020). Uzaktan eğitim öğrencilerinin basılı ve dijital ortamdaki sınav başarılarının karşılaştırılması [Comparison of distance education students' exam success in print and digital media]. $A U A d, 6(1), 41-52$.

UN (1948). Universal Declaration of Human Rights. https://www.un.org/en/universaldeclaration-human-rights/index.html

UNESCO (2020a). School closures caused by Coronavirus (Covid-19). https://en.unesco.org/ covid19/educationresponse

UNESCO (2020b). Exams and assessments in COVID-19 crisis: fairness at the centre. https://en.unesco.org/news/exams-and-assessments-covid-19-crisis-fairness-centre

UNESCO (2020c). Distance Learning Strategies, What do we know about effectiveness? http://www.unesco.org/covid19EDwebinar

Wang, F. (2017). Research on the paperless examination in the university public computer laboratory. Proceedings of the 2017 International Conference on E-Society, E-Education and E-Technology (pp. 52-55). ACM Digital Library.

Yağcı, M. Ekiz, H., \& Gelbal, S. (2011). Çevrimiçi sınav ortamlarının ögrrencilerin akademik başarllarina etkisi [The effect of online exam environments on students' academic success]. 5th International Computer \& Instructional Technologies Symposium, Frrat University, Elazı̆̆ Turkey.

Yağcı, M., Ekiz, H.,\& Gelbal, S. (2015). Yeni Bir Çevrimiçi Sınav Modeli Geliştirilmesi ve Uygulanmas1 [Developing and Implementing a New Online Exam Model]. Ahi Evran Üniversitesi Kırşehir Ĕgitim Fakültesi Dergisi, 16(1), 269-288.

Yıldırım, A., \& Şimşek, H. (2008). Sosyal Bilimlerde Nitel Araştırma Yöntemleri (6. Baskı) [Qualitative research methods in the social sciences. (6th Edition)]. Seçkin Yayınevi.

Yıldırım, A., \& Şimşek, H. (2011). Sosyal Bilimlerde Nitel Araştırma Yöntemleri (8. Basım) [Qualitative research methods in the social sciences. ( $8^{\text {th }}$ Edition)]. Seçkin Yayınları

Yılmaz, Ö. (2016). Çevrimiçi sınav görüş anketi [Online examination assessment survey]. $e$ Kafkas Ë̆itim Araştırmaları Dergisi, 3(3), 26-33.

Yin, R. K. (1984). Case Study Research: Design and Methods. Sage Publications.

Yin, R. K. (2003). Case study research: Design and methods ( $3^{\text {rd }}$ ed.). Sage.

Zhao, Y. (2020). COVID-19 as a catalyst for educational change. Prospects, 49(1), 29-33. https://doi.org/10.1007/s11125-020-09477-y 